\title{
Activation of Human D3 Dopamine Receptor Inhibits P/Q-Type Calcium Channels and Secretory Activity in AtT-20 Cells
}

\author{
Eldo V. Kuzhikandathil and Gerry S. Oxford \\ Department of Cell and Molecular Physiology, University of North Carolina at Chapel Hill, Chapel Hill, \\ North Carolina 27599
}

\begin{abstract}
The D3 dopamine receptor is postulated to play an important role in the regulation of neurotransmitter secretion at both preand postsynaptic terminals. However, this hypothesis and the underlying mechanisms remain untested because of the lack of D3-selective ligands, paucity of appropriate model secretory systems, and the weak and inconsistent coupling of D3 receptors to classical signal transduction pathways. The absence of ligands that selectively discriminate between D3 and D2 receptors in vivo precludes the study of D3 receptor function in the brain and necessitates the use of heterologous expression systems. In this report we demonstrate that activation of the human D3 dopamine receptor expressed in the AtT-20 neuroendocrine cell line causes robust inhibition of P/Q-type cal-
\end{abstract}

The pharmacological properties (Freedman et al., 1994) and expression patterns of the D3 dopamine receptor in the brain have been detailed (Bouthenet et al., 1991), and its role in pathological disorders such as schizophrenia has been postulated (Schwartz et al., 1993). However, the absence of D3 selective ligands has made it difficult to discriminate its role in native tissues (Burris et al., 1995), and attempts to identify D3 receptor signaling pathways in heterologous expression systems have revealed primarily only weak coupling to known effectors (Missale et al., 1998).

The D3 receptor has been proposed to function as an autoreceptor regulating the release of dopamine (Rivet et al., 1994). This hypothesis has been difficult to test, given the absence of truly D3 selective ligands. Recent studies in D3 receptor knockout mice have suggested that the D3 receptor is not an autoreceptor but plays an alternative role in the regulation of dopamine secretion (Accili et al., 1996; Koeltzow et al., 1998). Another recent study using an antisense approach to target selectively the D3 receptor function in vivo demonstrated a role for the D3 receptor in modulating synaptic transmission in nigrostriatal neurons (Tepper et al., 1997). Still other studies have indicated that D2/D3 selective ligands can inhibit the secretion of dopamine in vivo (Rivet et al., 1994; Gobert et al., 1996). The mechanism by which D3 receptors might inhibit dopamine secretion in these systems remains unknown. One previous study, using differentiated NG108 cells transfected with the D3 receptor, reported a

\footnotetext{
Received Oct. 12, 1998; revised Dec. 8, 1998; accepted Dec. 9, 1998.

This work was supported by Grants from National Institutes of Health (NS18788) and Hoechst-Marion-Roussel Pharmaceuticals. We express our appreciation to Rakhshi Khan and Anthony Lazaro for expert technical assistance.

Correspondence should be addressed to Gerry S. Oxford, Ph.D., Department of Cell and Molecular Physiology, Campus Box 7545, 452 Medical Science Research Building, University of North Carolina, Chapel Hill, NC 27599.

Copyright (C) 1999 Society for Neuroscience 0270-6474/99/191698-10\$05.00/0
}

cium channels via pertussis toxin-sensitive G-proteins. In addition, using the vesicle trafficking dye FM1-43, we show that D3 receptor activation significantly inhibits spontaneous secretory activity in these cells. Our results not only support the hypothesis that the D3 receptor can regulate secretory activity but also provide insight into the underlying signaling mechanisms. We propose a functional model in which the D3 receptor tightly regulates neurotransmitter release at a synapse by only allowing the propagation of spikes above a certain frequency or burst-duration threshold.

Key words: D3 dopamine receptor; calcium channels; secretion; FM1-43; AtT-20 cells; high-pass filter

weak inhibition of calcium currents but did not identify either the calcium channels involved or the mechanism of coupling (Seabrook et al., 1994).

AtT-20 mouse pituitary cells express several G-protein-coupled receptors, including somatostatin (Patel et al., 1994), muscarinic (Jones, 1992), and substance P receptors (Winkler et al., 1995) as well as a wide variety of ion channels. AtT-20 cells have been used previously for studying the function of transfected opioid receptors (Garcia et al., 1998), cannabinoid receptors (Mackie et al., 1995), and the regulation of stimulus-secretion coupling (Loechner et al., 1996), because they secrete the neurotransmitter acetylcholine (Carmeliet and Denef, 1989) and the peptide hormone, adrenocorticotropic hormone (ACTH) (Richardson and Schonbrunn, 1981). We have shown recently that the D3 receptor can activate robustly the G-protein-coupled inward rectifier potassium (GIRK) channels in AtT-20 cells (Kuzhikandathil and Oxford, 1997).

In this paper we show that human D3 receptors expressed in AtT-20 cells coordinately can inhibit voltage-dependent calcium channels, calcium influx, and secretory activity. Using specific inhibitors of calcium channel subtypes, we demonstrate that the D3 receptor couples to $\mathrm{P} / \mathrm{Q}$-type, but not to L-type, calcium channels. This coupling is mediated via G-proteins of the $\mathrm{G}_{\mathrm{o}}$ or $\mathrm{G}_{\mathrm{i}}$ subclass. Using the vesicle-tracking dye FM1-43 to monitor total secretory activity, we demonstrate that $\mathrm{D} 3$ receptor agonist significantly inhibits total secretory activity in these cells. These results provide new evidence for the role of the D3 receptor in the regulation of secretion and establishes the AtT-20 cell line as an excellent model system in which to examine the underlying signaling mechanisms.

\section{MATERIALS AND METHODS}

Cell culture and transfection. AtT-20 mouse pituitary cells were obtained from Dr. Sharon Milgram (University of North Carolina, Chapel Hill, 
NC) and grown in Ham's F10 medium with 5\% FBS, 20\% heatinactivated horse serum, $200 \mathrm{~mm}$ glutamine, and $1 \mathrm{mg} / \mathrm{ml}$ gentamicin. AtT-20 cells stably expressing the human D3 receptor (AtT-D3 cells) were generated by clonal selection after a Pfx-2 reagent (Invitrogen, San Diego, CA) mediated transfection and were maintained in $500 \mu \mathrm{g} / \mathrm{ml}$ of Geneticin (G418). The plasmid expressing the human D3 receptor was a gift from Dr. Tony Sandrasagra (Hoechst-Marion-Roussel Pharmaceuticals, Somerville, NJ). For electrophysiological characterization the cells were plated onto glass coverslips coated with $40 \mu \mathrm{g} / \mathrm{ml}$ poly-L-lysine.

Electrophysiology. Agonist-activated currents were measured in AtT-20 cells by the whole-cell patch-clamp technique with the use of either an Axopatch 1B or Axopatch 200 amplifier (Axon Instruments, Foster City, CA). Patch pipettes were constructed from N51A glass (Drummond, Broomall, PA), coated with dental wax (Kerr Sticky wax, Romulus, MI), and polished on a homemade microforge at $600 \times$ magnification. Currents were elicited by depolarizing step voltage commands $(0 \mathrm{mV})$ from holding potentials of either -40 or $-80 \mathrm{mV}$. The current responses were normalized by the cell capacitance $(\mathrm{pA} / \mathrm{pF})$ to account for variation in cell size. Calcium channel function was assayed with $\mathrm{Ba}^{2+}$ as a charge carrier. The external solution used for $\mathrm{Ba}^{2+}$ current measurements contained (in mM): $125 \mathrm{NaCl}, 10$ TEA-Cl, $10 \mathrm{BaCl}_{2}, 1 \mathrm{MgCl}_{2}, 10$ HEPES, and 10 glucose. The pipette solution contained (in $\mathrm{mM}$ ): 50 $\mathrm{CsCl}, 1$ EGTA, $90 \mathrm{~N}$-methyl-D-glucamine (NMDG), 90 aspartic acid, 5 $\mathrm{NaCl}, 1 \mathrm{MgCl}_{2}, 10 \mathrm{HEPES}, 10$ glucose, and an ATP-regenerating system. To block $\mathrm{Na}^{+}$currents during $\mathrm{Ca}^{2+}$ current measurements, we added tetrodotoxin (TTX; $1 \mu \mathrm{M}$, Sigma, St. Louis, MO) to both the external and drug solutions.

Drugs and toxins. Quinpirole, 7OH-DPAT, and somatostatin (Research Biochemicals, Natick, MA) were used at a concentration of 100 $\mathrm{nM}$, unless otherwise indicated. Calcium channel antagonists were made up in stock solutions and diluted on the day of the experiment. Nimodipine (Calbiochem, San Diego, CA) was made up as a $10 \mathrm{~mm}$ stock in 95\% ethanol; therefore, control traces were obtained by treating cells with an appropriate concentration of the ethanol solvent. Stock solutions of $\omega$-conotoxin GVIA, $\omega$-conotoxin MVIIC, and $\omega$-agatoxin IVA (Calbiochem and Alomone Labs, Jerusalem, Israel) were made up in distilled water at a concentration of $1 \mathrm{mM}, 10 \mu \mathrm{M}$, and $2 \mu \mathrm{M}$, respectively. For electrophysiological experiments the drug solutions were delivered at the indicated concentrations to cells via a multi-barreled micropipette array. For imaging experiments the drugs were applied by bath exchange.

Intracellular calcium imaging. The cells on glass coverslips were rinsed in PBS and incubated at $37^{\circ} \mathrm{C}$ in $5 \mu \mathrm{M}$ fluo-3 AM (Molecular Probes, Eugene, OR) for $30 \mathrm{~min}$. Cells were rinsed in standard external solution (SES) and placed in a glass bottom chamber on an inverted microscope stage (Nikon Diaphot). Drug and control solutions were applied by using a continuous flow bath exchange system. After excitation at $485 \mathrm{~nm}$, the fluorescence emission was bandpass-filtered at $535 \mathrm{~nm}$, collected via a quartz phase objective ( 40 or $100 \times$ ), amplified by a Videoscope KS-1381 intensifier, and passed to a Dage 72 CCD camera. Video images were captured with the Image-1 software package (Universal Imaging, West Chester, PA). This software allows for the logging of fluorescence intensity versus time for several cells as a measure of intracellular $\left[\mathrm{Ca}^{2+}\right]$ changes (arbitrary units).

Imaging vesicle trafficking. FM1-43 dye (Molecular Probes) was added to control or drug solutions at a final concentration of $2 \mu \mathrm{M}$ and applied directly to the cells, using a continuous flow bath exchange system in the experimental chamber described above. The dye and drug solutions were made up in SES that contained (in mM): $145 \mathrm{NaCl}, 5 \mathrm{KCl}, 2 \mathrm{CaCl}_{2}, 1$ $\mathrm{MgCl}_{2}, 10 \mathrm{HEPES}$, and 10 glucose. Cells plated on glass coverslips were imaged with a Videoscope intensifier and a Pentamax cooled CCD camera (Princeton Instruments, Trenton, NJ). To monitor and quantify changes in fluorescence, we defined rectangular regions of interest corresponding to highly fluorescent areas of cell-cell contact with the imaging software (Metamorph, Universal Imaging). Changes in fluorescence were monitored during cycles of solution exchange and are represented in arbitrary intensity units.

Statistical methods. The Student's $t$ test was performed on relevant data with the use of SigmaPlot (SPSS, Chicago, IL). In the $t$ test the data were considered statistically different when the probability value was $<0.05$. The $\chi^{2}$ test was performed by formulating a hypothesis and comparing the observed and expected data. A $\chi^{2}$ table was used to obtain the probability value for a given $\chi^{2}$ value. The observed experimental data support the formulated hypothesis when the probability value is $>0.05$.

\section{RESULTS}

\section{AtT-20 cells express voltage-dependent calcium} channels that are inhibited by somatostatin

Dopamine D3 receptors are not expressed natively in isolation in any particular neuronal population or in any neoplastic neuronal cell line. Therefore, to explore the functional effects of human D3 receptors on neurotransmitter or peptide hormone release, we found it necessary to identify an appropriate secretory cell system in which D3 receptors might be expressed. AtT-20 mouse pituitary cells are a neuroendocrine cell line that synthesizes and secretes both acetylcholine (Carmeliet and Denef, 1989) and ACTH (Richardson and Schonbrunn, 1981). They express somatostatin and muscarinic receptors (Jones, 1992; Patel et al., 1994) that couple to potassium (Kozasa et al., 1996; Takano et al., 1997) and calcium channels (Loechner et al., 1996) and regulate the secretion of ACTH. These features suggested that this cell line might serve as a convenient system to evaluate the functional role of heterologously expressed D3 receptors on neurotransmitter and peptide hormone secretion. We first chose to characterize and verify some of the properties of this cell line independently, using electrophysiological and imaging techniques.

Current-clamp recordings in Figure $1 A$ show that AtT-20 cells are spontaneously active, generating action potentials with complex characteristics orchestrated by a variety of ion channels. In particular, action potentials exhibiting long depolarized plateaus are seen periodically. Intracellular calcium imaging that uses the dye fluo-3 AM reveals an increase in calcium influx during the periods of spontaneous activity (Fig. $1 B$ ) qualitatively mirroring the electrical activity. Thus, it is clear that spontaneous calcium changes are present that could support spontaneous, regulated secretion of ACTH or acetylcholine. This increase in intracellular calcium presumably arises from influx through voltagedependent calcium channels.

\section{Human D3 dopamine receptors couple to voltage- dependent calcium channels when expressed in At $\mathrm{T}-20$ cells}

To investigate the possible coupling of D3 receptors to calcium channels and any functional consequences of the coupling on neurotransmitter and hormone secretion, we created an AtT-20 cell line stably expressing the human D3 receptor (AtT-D3 cells). We previously have characterized the expression and binding properties of the D3 receptor in this cell line (Kuzhikandathil and Oxford, 1997), yielding a receptor density of $1624 \pm 93 \mathrm{fmol} / \mathrm{mg}$ protein $(n=3)$. Figure $2 A$ illustrates the inhibition of peak barium currents under voltage clamp in an untransfected control AtT-20 cell exposed to $100 \mathrm{~nm}$ somatostatin, but not to $100 \mathrm{~nm}$ quinpirole (a dopamine receptor agonist). In contrast, the activation of human D3 receptors by $100 \mathrm{~nm}$ quinpirole in AtT-D3 cells significantly inhibits barium currents through voltagedependent calcium channels (Fig. $2 B$ ). The inhibition of voltagedependent calcium channels by quinpirole also is reflected in a decrease of spontaneous calcium influx into these cells as assessed by fluo-3 fluorescence changes (Fig. 2C). The D3 receptormediated inhibition of spontaneous calcium influx desensitizes on prolonged application of $100 \mathrm{~nm}$ quinpirole; however, the addition of $100 \mathrm{~nm}$ somatostatin after desensitization of the D3 receptor can sustain the inhibition of calcium influx (Fig. 2C). In such experiments we observed that the addition of both $100 \mathrm{~nm}$ quinpirole and $100 \mathrm{~nm}$ somatostatin significantly inhibited calcium influx (Fig. 2C,D) associated with the spontaneous action potentials. 
A.

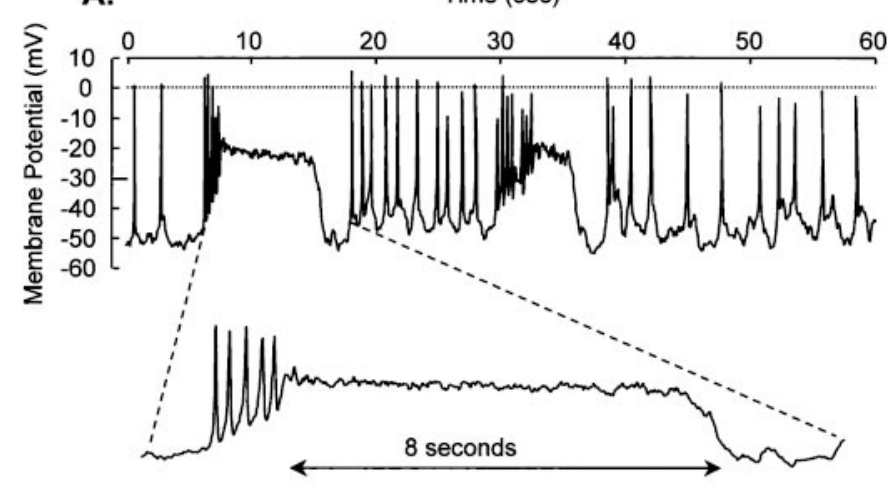

B.

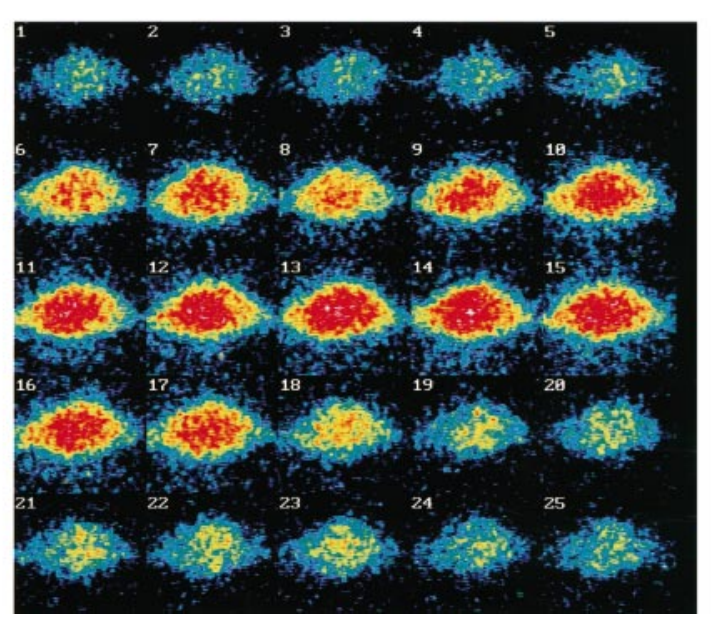

Figure 1. Untransfected AtT-20 cells exhibit increases in calcium influx during spontaneous activity and express multiple types of calcium currents that are inhibited partially by somatostatin, but not by quinpirole. $A$, Whole-cell current-clamp recording from a single AtT-20 cell demonstrates that these cells fire spontaneous action potentials, periodically developing long plateau depolarizations. $B$, Pseudo-color images of increases in fluo-3 fluorescence in a single AtT-20 cell presumably firing a plateau-like action potential. Consecutive images (numbered) were captured at $1 \mathrm{sec}$ intervals. "Hotter" colors correspond to increased calcium on an arbitrary scale.

Quinpirole inhibited barium currents in a dose-dependent manner, with maximal inhibition observed with $100 \mathrm{~nm}$ quinpirole, as illustrated for one cell in Figure $3 A$. Cumulative data from 12 cells in Figure $3 B$ show that, although $10 \mathrm{~nm}$ quinpirole inhibits barium currents by $14.7 \pm 2.0 \%, 100 \mathrm{~nm}$ quinpirole and $100 \mathrm{~nm}$ 7OH-DPAT (a putative D3 selective agonist) inhibit barium currents $26.2 \pm 4.5$ and $20.4 \pm 3.1 \%$, respectively. The inhibition by both $\mathrm{D} 3$ receptor agonists is robust but is still less than the $37.2 \pm 5.6 \%$ inhibition by $100 \mathrm{~nm}$ somatostatin acting on endogenous receptors. In all cases the residual agonist-resistant barium current is blocked completely by $200 \mu \mathrm{M}$ cadmium (data not shown).

The robust and consistent inhibition of calcium channels in AtT-D3 cells by quinpirole allowed us also to examine the desensitization of this coupling. Figure $3 C$ shows that peak inhibition of barium current was observed after only $15 \mathrm{sec}$ of quinpirole application. In the continued presence of $100 \mathrm{~nm}$ quinpirole, this response gradually decreased to less than one-half the original inhibition over a period of $3 \mathrm{~min}$. It is notable that D3 receptor coupling to GIRK channels in these cells exhibits comparable desensitization (Kuzhikandathil and Oxford, 1997), suggesting that the desensitization is at the level of the receptor, rather than postreceptor, signaling elements.

\section{D3 receptor-mediated inhibition of barium currents is blocked by pertussis toxin}

Although D3 receptors exhibit sequence homology with the G-protein-coupled D2 receptor, observations on the involvement of G-proteins in D3 receptor signaling are equivocal (Robinson and Caron, 1997; Missale et al., 1998). To explore the role of G-proteins in coupling the human D3 receptor to voltagedependent calcium channels, we tested the ability of pertussis toxin (PTX) to block the observed inhibition of barium currents in AtT-D3 cells. PTX ADP-ribosylates the $G_{i}$ and $G_{o}$ subclasses of heterotrimeric G-proteins and inhibits their ability to exchange GDP for GTP. The inhibition of GDP-GTP exchange prevents the dissociation of $\alpha$-and $\beta \gamma$-subunits, compromising their ability to affect downstream effectors. Figure 4 shows that treatment of AtT-D3 cells with $250 \mathrm{ng} / \mathrm{ml}$ of PTX for $4 \mathrm{hr}$ completely blocked the inhibition of barium currents by the D3 receptor agonists quinpirole and 7OH-DPAT as well as inhibition by somatostatin. Thus G-proteins of the $G_{i}$ or $G_{o}$ subclasses are implicated as the mediators of D3 receptor effects on voltage-dependent calcium channels. The ability of PTX to block somatostatin-mediated inhibition of voltage-dependent calcium channels has been reported previously in this cell line (Reisine et al., 1988).

\section{D3 receptor inhibits $P / Q$-type calcium channels in AtT-20 cells}

Previous studies have shown that AtT-20 cells express L- and $\mathrm{P} / \mathrm{Q}$-type calcium channels. Furthermore, L-type channels appear to be primarily responsible for mediating ACTH release induced by either corticotropin-releasing hormone $(\mathrm{CRH})$ or $\mathrm{K}^{+}$depolarization (Loechner et al., 1996). In contrast to studies of which calcium channels are involved in stimulatory secretion responses in AtT-20 cells, no comparable studies have been performed to define the subtypes of calcium channels to which inhibitory signals couple to effect reductions in basal secretion. We thus were interested in determining the identity of calcium channels that coupled to the transfected D3 receptor as well as to endogenous somatostatin receptors in AtT-20 cells and to compare the results with the calcium channel subtype profile of stimulatory signaling pathways.

To accomplish this, we tested the effects of a series of calcium channel subtype selective drugs and toxins on the magnitude of control barium currents and on the degree of inhibition induced by quinpirole (via D3 receptors) or somatostatin (via SST receptors). The data obtained by using selective drugs and toxins that target specific calcium channels are summarized in Table 1 . We first examined the pharmacologically defined distribution of calcium channel subtypes by applying nimodipine (L-type), $\omega$-conotoxin GVIA (N-type), $\omega$-agatoxin IVA (P/Q-type), and $\omega$-conotoxin MVIIC (Q-type) to AtT-D3 cells. Then barium currents were measured during a step depolarization to $0 \mathrm{mV}$ from a holding potential of -80 or $-40 \mathrm{mV}$ (for experiments in which nimodipine was used). Nimodipine (10 $\mu \mathrm{M})$ inhibited control barium currents by $\sim 32 \%$, accounting for the largest of the drug-sensitive components. N-type channels accounted for only $3 \%$ of control barium currents, whereas P- and Q-type channels constituted $12.5 \%$ of the currents. Thus nearly one-half of the total current that was observed was resistant to any of the agents used.

We then determined the degree of inhibition of barium currents by quinpirole or somatostatin in the absence or presence of 
A)

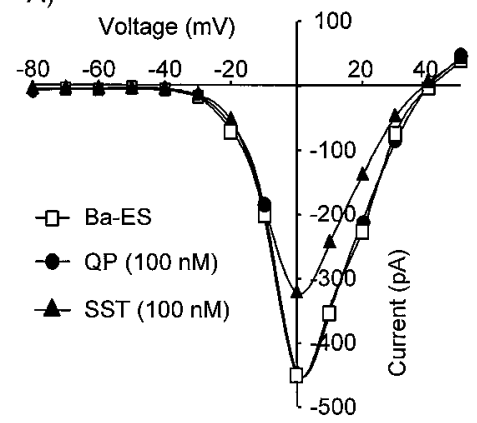

C)

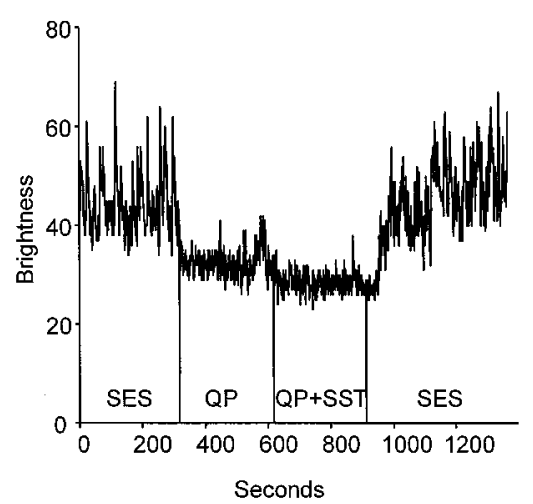

B)

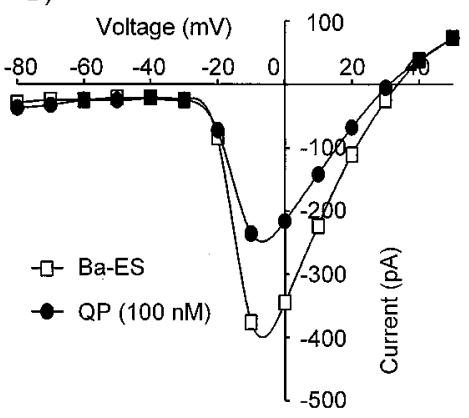

D)

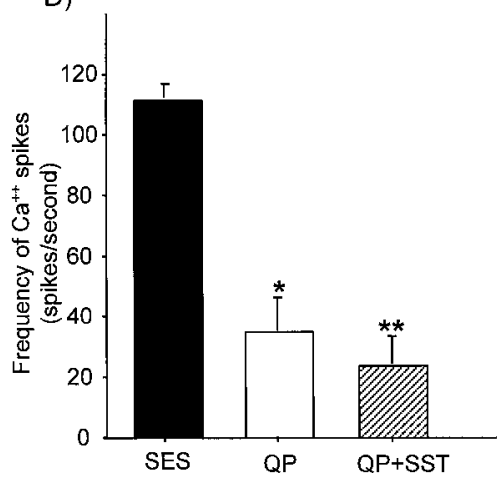

Figure 2. Activation of human D3 receptors in transfected AtT-20 cells inhibits barium currents and calcium influx during spontaneous activity. $A$, Current versus voltage plot of barium currents (values taken at $15 \mathrm{msec}$ ) evoked by steps to the indicated potentials in an untransfected AtT-20 cell during control $(B a-E S), 100 \mathrm{~nm}$ somatostatin $(S S T)$, or $100 \mathrm{~nm}$ quinpirole $(Q P)$ treatment. $B$, Current versus voltage plots of barium currents evoked at the indicated test potentials in an AtT-20 cell expressing the human D3 receptor (AtT-D3 cell). Current traces were obtained under voltage clamp during treatment with control (Ba-ES; open squares) or $100 \mathrm{~nm}$ quinpirole $(Q P$; filled circles) solutions. $C$, Spontaneous spiking fluctuations in intracellular calcium imaged as fluo-3 fluorescence are inhibited in an AtT-D3 cell by $100 \mathrm{~nm}$ quinpirole $(Q P)$ or $100 \mathrm{~nm}$ quinpirole plus $100 \mathrm{~nm}$ somatostatin $(Q P+S S T)$. The inhibition is reversed after washout with control SES. $D$, Mean \pm SEM calcium spike frequency (spikes/sec) for 12 AtT-D3 cells during the indicated treatments illustrate the inhibition of calcium influx by QP (100 $\mathrm{nM}$; open bar) or QP+SST (100 nM each; striped bar). Values are significantly different $\left({ }^{*},{ }^{*} p<0.001 ; n=12\right)$ from control SES values.

A)

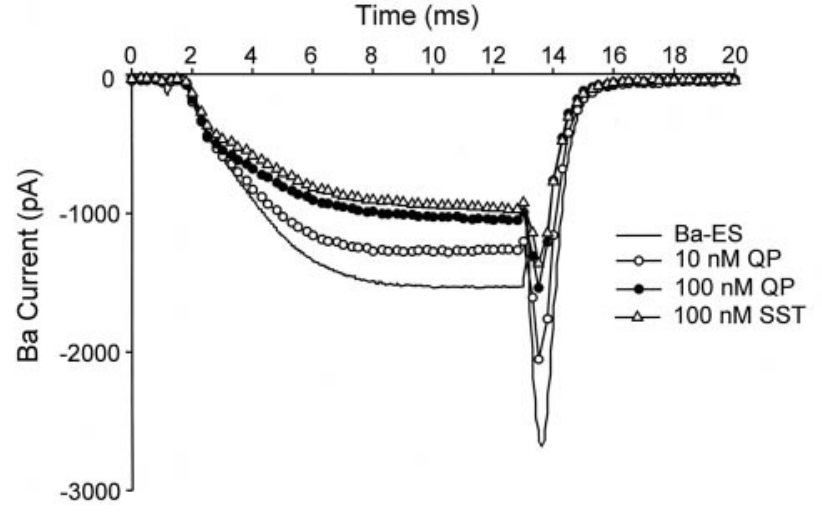

\section{B)}

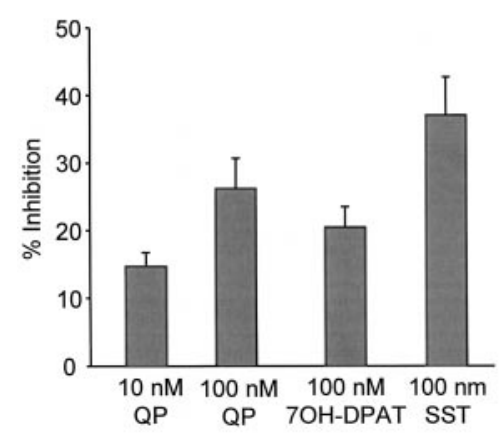

C)

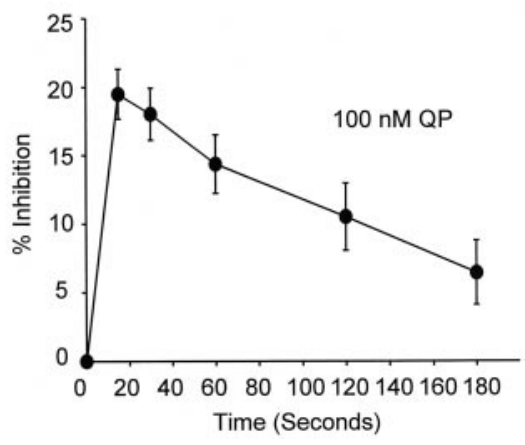

Figure 3. Agonists for D3 receptors inhibit barium currents in AtT-D3 cells, an effect that desensitizes dramatically. $A$, Barium currents in a single AtT-D3 cell evoked by test voltage steps from -80 to $0 \mathrm{mV}$. Control currents in Ba-ES are indicated by the solid line. The cell subsequently was treated with either quinpirole $(Q P ; 10 \mathrm{nM}=$ open circles and $100 \mathrm{nM}=$ filled circles) or $100 \mathrm{~nm}$ somatostatin (SST; open triangles). For the purpose of clarity every fifth data point is plotted in these traces. $B$, Cumulative data showing the mean percentage of inhibition of the peak barium current \pm SEM measured at $0 \mathrm{mV}$ by the indicated agonists $(n=12$ cells $)$. The values are significantly different from control Ba-ES $(p<0.05)$. $C$, The mean \pm SEM percentage of inhibition induced by quinpirole (100 nM) in AtT-D3 cells decreases in the continuous presence of quinpirole; $n=15$ cells. 


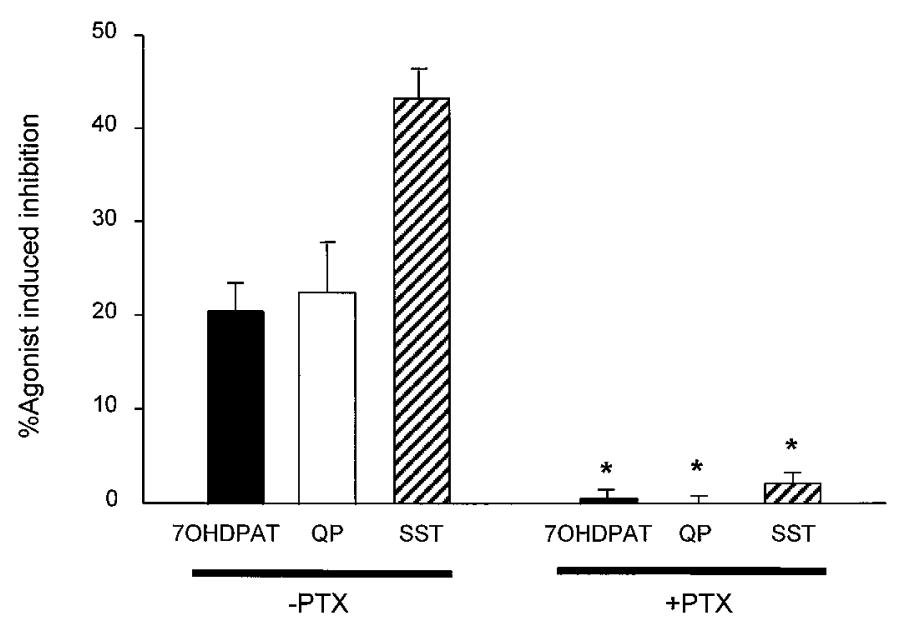

Figure 4. Pertussis toxin $(P T X)$ prevents the coupling of transfected human D3 receptors to calcium channels in AtT-D3 cells. Shown is the percentage of agonist-mediated inhibition of barium currents by $100 \mathrm{nM}$ 7OH-DPAT, $100 \mathrm{~nm}$ quinpirole $(Q P)$, or $100 \mathrm{~nm}$ somatostatin $(S S T)$ in the absence $(-)$ or presence $(+)$ of PTX. AtT-D3 cells were treated with $250 \mathrm{ng} / \mathrm{ml}$ of PTX for $4 \mathrm{hr}$ before whole-cell recording was performed in voltage clamp. The observed reduction of effect by PTX is statistically significant for all three agonists. ${ }^{*} p<0.001 ; n=11$.

the various channel antagonists. For the cells used in this study, quinpirole and somatostatin inhibited currents by 19 and 33\%, respectively, under control conditions. Quinpirole and somatostatin combined with nimodipine inhibited barium currents by $\sim 48$ and $62 \%$, respectively (Table 1 ). If the effects of nimodipine and the receptor agonists are on exclusive populations of calcium channels, then one would predict that the effects of simultaneous application of these agents would be additive. This, in fact, is what was observed. No significant differences $\left(p>0.5, \chi^{2}\right.$ test) were seen between the observed inhibition of currents by either agonist in combination with nimodipine and the predicted inhibition based on the assumption of purely additive effects (Table 1, values in square brackets). These results suggest that, whereas L-type channels form a significant portion of the calcium channel population in AtT-20 cells, neither the D3 receptor nor the somatostatin receptor can couple effectively to this subtype of calcium channel.

The N-type calcium channel blocker $\omega$-conotoxin GVIA by itself did not inhibit barium currents significantly (3\%), nor did it attenuate inhibition of currents by quinpirole $(20 \%)$ or somatostatin (32\%). This result is consistent with a previous report of minimal N-type calcium currents in AtT-20 cells (Loechner et al., 1996).

In contrast to the observations on L- and N-type channels, combined application of the receptor agonists and P/Q-type channel blockers yields significantly less $\left(p<0.02, \chi^{2}\right.$ test) inhibition of barium current than the prediction of exclusive and additive effects. Data in Table 1 show that, when quinpirole or somatostatin is added in combination with $\omega$-agatoxin IVA, the barium current inhibition is only 22 and $36 \%$, respectively. This inhibition is significantly less than the expected additive inhibition (31 and $46 \%$ ). This nonadditive effect also is observed when the Q-type calcium channel blocker $\omega$-conotoxin MVIIC is used in combination with quinpirole or somatostatin, in which case the observed effect (17 and 33\%, respectively) is significantly less than an expected additive effect (32 and 46\%, respectively). These data strongly suggest that in AtT-D3 cells the D3 dopa- mine and somatostatin receptors predominantly couple to P- and Q-type calcium channels. Although a subset of D3 receptors and somatostatin receptors couples to $\mathrm{P} / \mathrm{Q}$-type calcium channels, a significant portion also couples to toxin-resistant calcium channels (Table 1). The toxin-resistant barium currents were blocked completely by $200 \mu \mathrm{M}$ cadmium, suggesting that these were indeed barium currents flowing through calcium channels (data not shown).

\section{Activation of D3 receptors inhibits spontaneous vesicular secretion in AtT-20 cells}

To examine the functional consequences of D3 receptor coupling to calcium channels, we took advantage of the secretory properties of AtT-20 cells. Data in Figure 1, $A$ and $B$, illustrated that these cells are spontaneously active, raising the possibility that they exhibit spontaneous basal secretion. To assess the secretory activity (related to either ACTH and acetylcholine secretion) in these cells, we used the fluorescent membrane dye FM1-43. This dye stains membranes of recycled synaptic vesicles by virtue of an increase in fluorescence in a hydrophobic environment (Angleson and Betz, 1997). During exocytosis the dye is released from the secretory vesicles into an aqueous environment, resulting in a decrease in fluorescence. By monitoring the increase and subsequent decrease in dye fluorescence, it is possible to measure general secretory activity qualitatively and quantitatively (Betz et al., 1996).

Given the ability of AtT-20 cells to secrete both a peptide hormone $(\mathrm{ACTH})$ and a neurotransmitter (acetylcholine), we were interested in determining the spatial pattern of secretory activity. Specifically, we wondered if the secretory activity in AtT-20 cells was global or localized. Unexpectedly, we observed that incubation with $2 \mu \mathrm{M}$ FM1-43 results in fluorescent staining primarily at sites of cell-cell contact in untreated AtT-20 cells (Fig. 5). This result suggests that the secretory activity measured by using this dye is highly localized and underscores the neuronallike phenotype of this cell line. Washing the cells with SES without dye results in destaining (decrease of fluorescence) over a period of 10-20 min, reflecting dye being released from secretory vesicles, presumably a result of the spontaneous electrical activity prevalent in these cells (see Fig. 1). These results and other published work indicate that the dye FM1-43 can be used effectively to monitor spontaneous and induced secretory events (Angelson and Betz, 1997).

We have observed that continuous and prolonged exposure (20-30 min) of AtT-20 cells to FM1-43 can result in a more global staining of the cell soma, likely as a result of endosomal incorporation of the dye. Therefore, in our experimental design we incubated the cells with $2 \mu \mathrm{M}$ FM1-43 for a period of only 1-5 min before washing away the dye either in control or drug solutions. Regions of high fluorescent staining (and presumptive secretory activity) were identified and digitally isolated; the fluorescence changes in these specific regions were monitored as the cells were treated with various drugs (as described in Material and Methods).

Using this approach, we monitored the release of fluorescent dye from AtT-20 cells when the cells were washed under different conditions. We first compared destaining in solutions lacking calcium or those containing $100 \mathrm{~nm}$ quinpirole (D3 receptor agonist). Figure $6 A$ shows the changes in FM1-43 fluorescence in a single AtT-D3 cell during cycles of dye addition and withdrawal. When the dye is removed by using standard external solution 


\begin{tabular}{|c|c|c|c|c|}
\hline \multirow[b]{2}{*}{ Agonist/toxin } & \multirow[b]{2}{*}{ Calcium channel type } & \multicolumn{3}{|c|}{ Percentage of inhibition } \\
\hline & & Control (Ba-ES) & Quinpirole (100 nм) & Somatostatin $(100 \mathrm{~nm})$ \\
\hline Control (Ba-ES) & & 0 & $\begin{array}{l}19.11 \pm 1.22 \\
(n=52 \text { cells })\end{array}$ & $\begin{array}{l}33.38 \pm 2.32 \\
(n=21 \text { cells })\end{array}$ \\
\hline Nimodipine $(10 \mu \mathrm{M})(n=18$ cells $)$ & $\mathrm{L}$ & $31.81 \pm 3.81$ & $48.15 \pm 4.24[50.92]$ & $62.16 \pm 4.42[65.19]$ \\
\hline$\omega$-Conotoxin GVIA $(1 \mu \mathrm{M})(n=12$ cells $)$ & $\mathrm{N}$ & $2.82 \pm 1.63$ & $20.43 \pm 3.23[21.93]$ & $31.75 \pm 4.08[36.2]$ \\
\hline$\omega$-Agatoxin IVA $(50 \mathrm{~nm})(n=13$ cells $)$ & $\mathrm{P} / \mathrm{Q}$ & $12.27 \pm 2.34$ & $21.54 \pm 2.87^{*}[31.38]$ & $36.12 \pm 3.56^{*}[45.65]$ \\
\hline$\omega$-Conotoxin MVIIC (500 nM) $(n=14$ cells $)$ & Q & $12.55 \pm 1.86$ & $17.36 \pm 1.48^{*}[31.66]$ & $33.16 \pm 3.17^{*}[45.93]$ \\
\hline
\end{tabular}

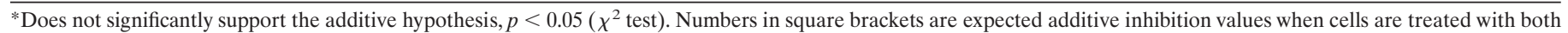
receptor agonist and calcium channel subtype antagonists.
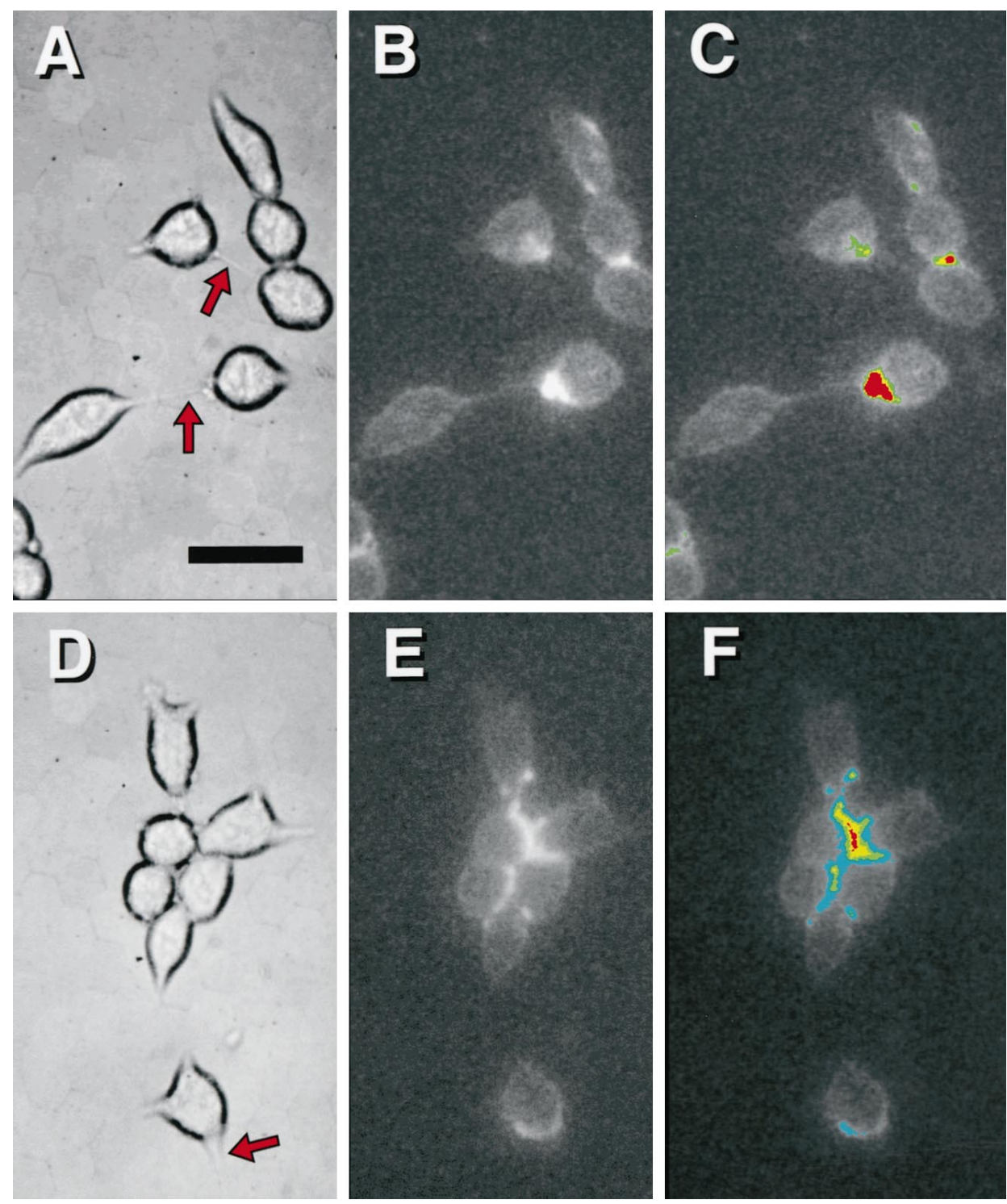

Figure 5. Secretory events occur predominantly at sites of cell-cell contact in AtT-20 cells. AtT-20 cells expressing the human D3 receptor were treated with $2 \mu \mathrm{M}$ FM1-43 dye, and interference contrast (left) and fluorescence images (center and right) for two groups of cells (top and bottom images) were captured as described in Materials and Methods. Occasional neurite-like processes projecting from cells and making contact with other cells are marked by the arrows. The images suggest that the maximal vesicle trafficking, as measured by an increase in FM1-43 fluorescence, occurs at sites of cell-cell contact. In the extreme right images the color scale indicates the relative fluorescence intensity, with hotter colors corresponding to increased vesicle cycling activity. Scale bar, $20 \mu \mathrm{m}$.

containing calcium (Fig. 6A, open circles), the fluorescence intensity decreases smoothly over a period of $20 \mathrm{~min}$. In contrast, when the dye is removed by using an external solution without calcium (Fig. $6 A$, filled circles) or one with $100 \mathrm{~nm}$ quinpirole plus calcium (Fig. 6A, open triangles), the fluorescence intensity does not decrease significantly until the external solution is switched back to SES.

The initial decrease in fluorescence intensity in these cells follows an approximately exponential time course, as shown for the data of Figure $7 A$, and hence was plotted in semilogarithmic form in Figure $6 B$. The data points were fit to a regression line, the slope of which defined the fluorescence decay rate. Fluorescence decay rates obtained during destaining in SES, zero calcium, or $100 \mathrm{~nm}$ QP for 13 different AtT-D3 cell pairs (i.e., at points of cell-cell contact) are shown in Figure $6 C$. The data strongly suggest that the fluorescence decay rate (an indication of 


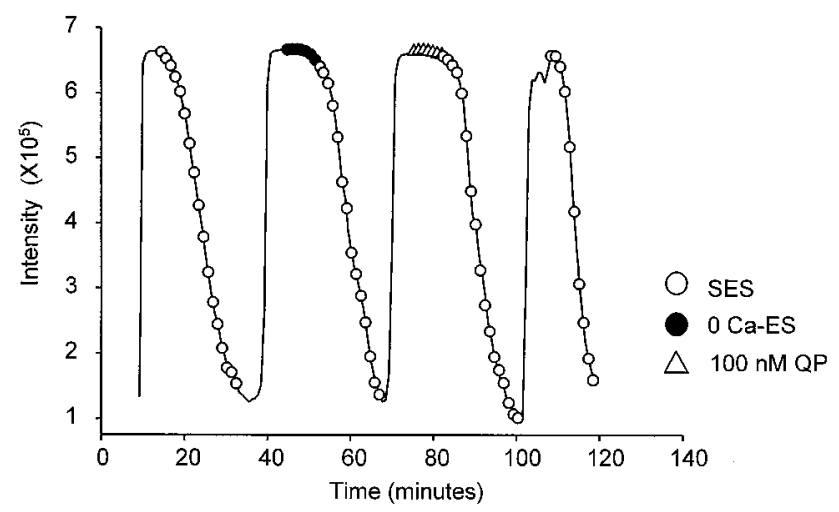

Figure 6. Spontaneous secretory activity in AtT-20 cells expressing the human D3 receptor is calcium-dependent and blocked by quinpirole. $A$, The fluorescence intensity at the site of cell-cell contact was monitored in a single pair of cells, as described in Materials and Methods. The cells were exposed periodically to $2 \mu \mathrm{M}$ FM1-43 for $\sim 3$ min (solid line) and then washed with standard external solution (SES; open circles) or solutions containing either no calcium ( 0 Ca-ES; filled circles) or $100 \mathrm{~nm}$ quinpirole (QP; open triangles). The fluorescence intensity is scaled in arbitrary units. $B$, The fluorescence time courses in the different wash conditions for the same cell shown in $A$ are shown on a semilogarithmic scale to permit kinetic comparison. Each data set was fit to a regression line. $C$, The mean fluorescence decay rate for each wash condition was calculated for 13 different cell junctions by averaging the slopes of individual data sets generated as described in $B$. The fluorescence decay rate is decreased significantly during wash with solutions lacking calcium $(0$ $C a-E S)$ or 100 nм quinpirole $(Q P) .{ }^{*} p<0.001 ; n=13$.

B)

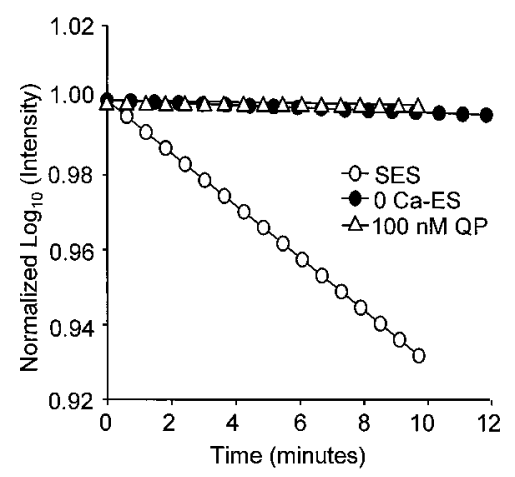

C)

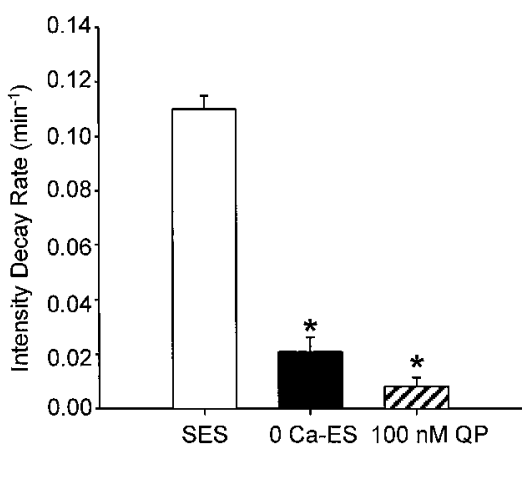

secretory rate) is suppressed dramatically in the absence of calcium or in the presence of the D3 receptor agonist quinpirole.

The electrophysiological data in Table 1 suggested that nimodipine inhibits $\sim 30 \%$ of barium currents and has an additive effect when combined with quinpirole, suggesting that the D3 receptor does not couple appreciably to L-type calcium channels in these cells. This raised an interesting possibility that the calcium channel population coupling to the D3 receptor might have a different functional effect on secretion than the L-type calcium channel. To test this possibility, we compared the rate of FM1-43 destaining in AtT-D3 cells in the presence of SES, $10 \mu \mathrm{M}$ nimodipine, or $100 \mathrm{~nm}$ quinpirole (Fig. 7). In Figure $7 A$ fluorescence decreases with significantly different time courses in SES, nimodipine, and quinpirole in a representative cell. In contrast to nimodipine, quinpirole is able to retard the destaining significantly. In Figure $7 B$ the average destaining time courses $(n=15$ cells) for washes in SES, nimodipine, or quinpirole are plotted on a semilogarithmic scale for kinetic comparison. The regression fits to each data set indicate the dramatic differences between quinpirole and nimodipine. The mean destaining rates for these cells are plotted for each condition in Figure $7 C$, illustrating that nimodipine and quinpirole decreased secretory activity by $\sim 25$ and $60 \%$, respectively. These results suggest that the calcium channels regulated by the D3 receptor have a more significant influence on spontaneous secretion in AtT-20 cells than do L-type calcium channels.

The results in Figures 6 and 7 suggest that, in AtT-20 cells expressing the human D3 receptor, spontaneous secretory activity assayed with FM1-43 is calcium-dependent and is only inhib- ited modestly by block of L-type calcium channels but is inhibited strongly by activation of the D3 receptor at least in part by its inhibition of $\mathrm{P} / \mathrm{Q}$-type and toxin-resistant calcium channels (Table 1).

\section{DISCUSSION}

The functional role of the D3 dopamine receptor has been difficult to study in behaving animals or in brain slices, primarily because of the lack of truly receptor selective ligands that can discriminate between D3 and D2 receptors (Burris et al., 1995). In an attempt to overcome this problem, many labs have transfected the cloned D3 receptor into different cell lines to examine whether it couples to traditional effector systems. However, perhaps because of the differences in the repertoire of G-proteins and other signaling proteins among different mammalian cell lines, these studies often have yielded weak or inconsistent results (Missale et al., 1998). Recently, we demonstrated that the human D3 receptor can couple robustly to GIRK channels in the AtT-20 mouse pituitary cell line (Kuzhikandathil and Oxford, 1997), suggesting that these cells might be a good system in which to evaluate the functional role of the D3 receptor. Because modulation of both GIRK channels and calcium channels conceivably could alter the secretory activity of a cell, the modulation of these channels by the heterologously expressed D3 receptor might be expected to change AtT-20 secretory activity. The results presented in this paper provide strong evidence for a functional role of the D3 receptor in regulating secretion.

Dopaminergic neurons in the midbrain project to various areas and release dopamine and colocalized neuropeptides during 


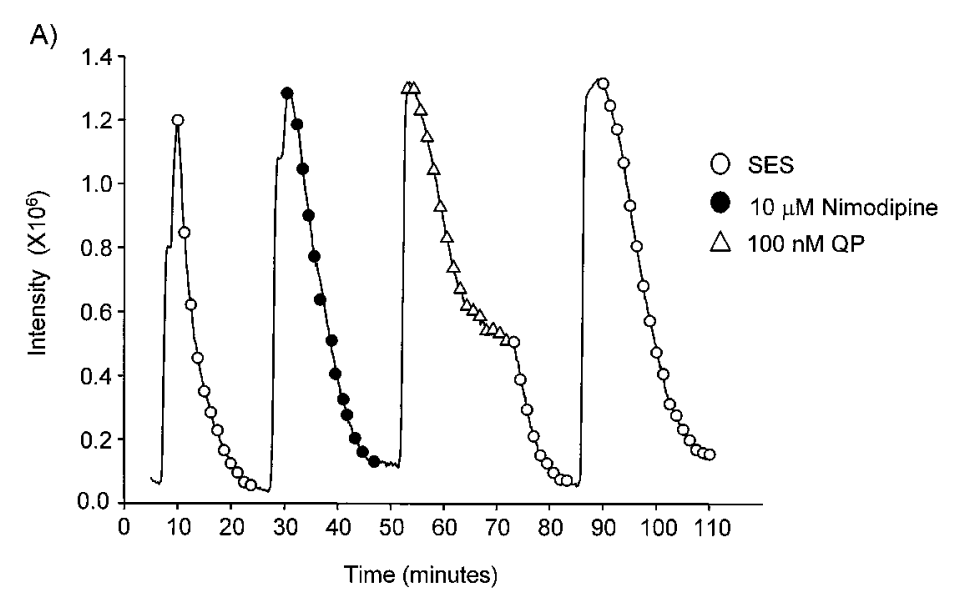

B)

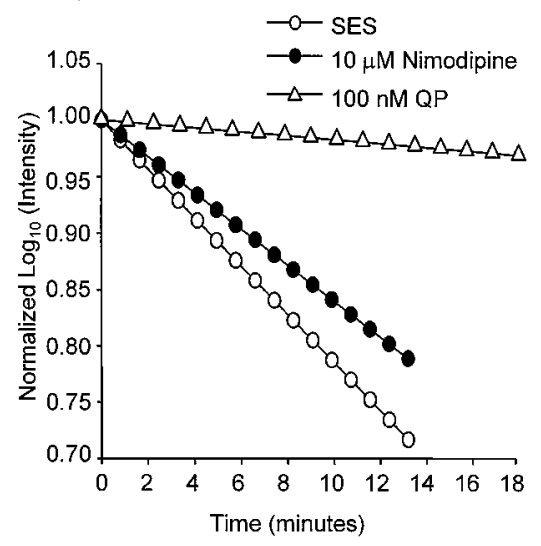

C)

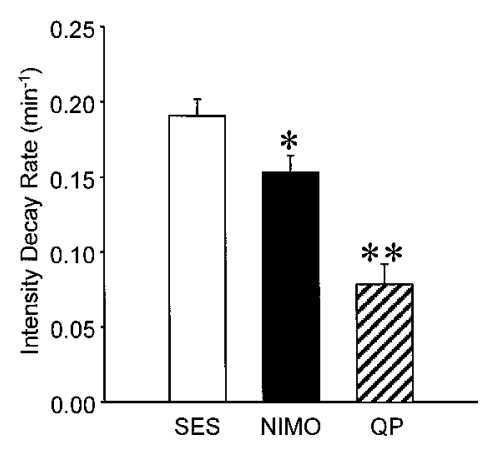

Figure 7. Quinpirole blocks spontaneous secretory activity more effectively than nimodipine in AtT-20 cells expressing the human D3 receptor. $A$, The fluorescence intensity at the site of cell-cell contact was monitored in a single pair of cells as described in Materials and Methods. The cells were exposed periodically to $2 \mu \mathrm{M}$ FM1-43 for $\sim 3 \mathrm{~min}$ (solid line) and then washed with standard external solution (SES; open circles) or solutions containing either $10 \mu \mathrm{M}$ nimodipine (filled circles) or $100 \mathrm{~nm}$ quinpirole (QP; open triangles). $B$, The mean fluorescence intensity was obtained by averaging values at $1 \mathrm{~min}$ intervals for 15 different cell pairs during the different treatment conditions (SES, nimodipine, or quinpirole) and are plotted on a semilogarithmic scale. The data points (means) for the different treatment conditions were fit to regression lines. $C$, The mean fluorescence decay rate for the different wash conditions was obtained from averaging the slopes of regression fits for each individual cell pair. Both 10 $\mu \mathrm{M}$ nimodipine $(N I M O)$ and $100 \mathrm{nM}$ quinpirole $(Q P)$ significantly decreased the fluorescence decay rate. ${ }^{*} p<0.05$; ${ }_{* *}^{*} p<0.001 ; n=15$. bursts of activity (Overton and Clark, 1997). In the nucleus accumbens, dopamine depresses inhibitory synaptic transmission by reducing calcium influx into the presynaptic terminal but depresses excitatory transmission independently of calcium influx (Nicola and Malenka, 1997). Agonists for D2-like dopamine receptors have been shown to decrease the amplitude of EPSCs recorded from medium spiny neurons (Umemiya and Raymond, 1997) and also to inhibit spontaneous firing of dopaminergic neurons in the ventral tegmental area (Momiyama et al., 1996) and the substantia nigra (Bowery et al., 1994). Despite such observations the role of different subtypes of D2-like receptors in modulating synaptic transmission remains mainly unknown because of the lack of selective ligands. It has been suggested that the different firing patterns (bursts, irregular, and pacemaker) observed in dopaminergic neurons might trigger the involvement of different calcium channel subtypes (Zeilhofer et al., 1996). Although it appears that N- and P/Q-type calcium channels may contribute to synaptic transmission during low-frequency stimulation (Wu and Saggau, 1994), L-type channels more likely are activated by prolonged high-frequency stimulation (Bonci et al., 1998) or continuous depolarization (Koh and Hille, 1997). The ability to modulate the activity of different calcium channel subtypes therefore might provide insight into the role of different D2-like receptor subtypes in modulating synaptic transmission in dopaminergic neurons. Our results demonstrating the ability of the D3 receptor to inhibit P/Q-type calcium channels, to activate GIRK channels, and to reduce secretory activity greatly are consistent with the proposed role for the D3 receptor in inhibiting transmitter release in vivo.
The AtT-20 cells that we studied express L-, N-, P-, Q-, and T-type calcium channels (by electrophysiological and pharmacological criteria), and among these the L-type channels have been shown to be primarily responsible for $\mathrm{CRH}$ - and $\mathrm{KCl}$-induced ACTH release (Loechner et al., 1996). In contrast, the identity of calcium channels regulating basal ACTH release (triggered by spontaneous action potentials) as well as acetylcholine release in AtT-20 cells has not yet been determined. Our results and those of Loechner et al. (1996) suggest that L-type calcium channels may well be coupled preferentially to $\mathrm{CRH}$ release and only poorly coupled to acetylcholine release in AtT-20 cells. Indeed, it is quite likely that FM1-43 predominantly may monitor vesicle activity associated with acetylcholine release. Alternatively, P/Qtype channels may be coupled both to excitability and directly to the secretory process involved in FM1-43-sensitive vesicle activity. It is not possible yet to discriminate between a general suppression of firing and consequently a depression of calcium influx via any voltage-gated calcium channel and a specific interruption of calcium influx that couples to vesicle fusion via $\mathrm{P} / \mathrm{Q}$ type channels. We do not favor the direct involvement of this calcium channel subclass because we have provided previous evidence that GIRK channels also are activated by D3 receptors in these cells (Kuzhikandathil and Oxford, 1997). Both $\mathrm{K}^{+}$channel opening and $\mathrm{Ca}^{2+}$ channel block could effect an inhibition of secretion. We currently are initiating experiments to discriminate these two possibilities, using specific molecular tools to interrupt the function of each type of channel.

Our results demonstrate that, when expressed in AtT-20 cells, human D3 receptors can inhibit $\omega$-agatoxin-sensitive P/Q-type 
channels, but not L- or N-type calcium channels (Table 1). Among calcium channels the weight of current evidence suggests that the $\omega$-agatoxin-sensitive $\mathrm{P} / \mathrm{Q}$-type calcium channel subtype is the primary mediator of action potential-evoked transmitter release in the mammalian CNS (Dunlap et al., 1995). In rat cortical synaptosomes, for example, $\omega$-agatoxin significantly inhibits glutamate and dopamine release (Luebke et al., 1993; Turner et al., 1993). Interestingly, in acutely isolated rat amygdaloid neurons, somatostatin has been shown to inhibit $\mathrm{N}$ - and P/Q-type, but not L-type, calcium channels (Viana and Hille, 1996), results that are similar to our own observations in AtT-20 cells (Table 1). In contrast, L-type calcium channels appear to play a role only during prolonged high-frequency stimulation, presumably because these channels require a stronger depolarization to open (Koh and Hille, 1997; Bonci et al., 1998).

The ability of the D3 receptor to activate GIRK channels and inhibit P/Q-type (but not L-type) calcium channels suggests a novel role for D3 receptors in modulating synaptic impulse flow. We have developed a speculative model that is based on several key observations about the D3 receptor, including its high affinity for dopamine as well as its coupling to GIRK channels and calcium channels, both of which rapidly desensitize. It also is based on observations in the CNS that $\mathrm{N}$ - and P/Q-type calcium channels are activated by low-frequency stimulation, whereas L-type are activated by high-frequency stimulation. According to this model, low-frequency/weak stimulation that releases only limited amounts of dopamine would reduce further presynaptic release and also induce postsynaptic inhibition by inhibiting P/Qtype calcium channels and/or activating GIRK channels. In contrast, during a high-frequency/strong stimulation, calcium channels such as L-type (that are not modulated by D3 receptors) would be activated and trigger the release of larger amounts of dopamine from the presynaptic terminals, thus evoking a strong postsynaptic response presumably via other dopamine receptor subtypes. Such massive dopamine release rapidly could desensitize D3 receptors coupling to calcium and GIRK channels and successfully bypass the inhibitory influences of D3 receptor activation. The model speculates that the D3 receptor sets a threshold for synaptic transmission allowing strong impulses but inhibiting the flow of weak impulses. In this manner the D3 receptor would function as a high-pass filter, increasing the fidelity of neurotransmission at the dopaminergic synapse. As a high-affinity dopamine receptor subtype that couples to both $\mathrm{P} / \mathrm{Q}$-type calcium channels as well as GIRK channels, this receptor would regulate neurotransmitter release tightly at a synapse, only allowing the propagation of spikes above a certain frequency and/or burst-duration threshold.

Interestingly, in an in vivo study that examined the relationship between dopamine release and discharge activity in the rat nucleus accumbens (an area that expresses high levels of D3 receptor), it was demonstrated that dopaminergic terminals convert physiological impulse flow into dopamine release in a manner consistent with a high-pass filter, favoring bursts of action potentials (Suaud-Chagny et al., 1992). On the basis of our studies showing the ability of D3 receptors to activate GIRK channels and inhibit $\mathrm{P} / \mathrm{Q}$-type calcium channels (but not L-type calcium channels), we propose that the bias toward bursts of action potentials demonstrated in dopaminergic neurons may take advantage of the coupling features of the D3 dopamine receptor. In fact, such coupling mechanisms may help to shape the bursting behavior of such neurons. The hypothesis also is supported by the report of Tepper et al., 1997 that, when D3 receptor levels are decreased in vivo by antisense RNA, somatodendritic excitability increases, whereas the threshold current required for terminal excitability decreases. Currently, we are investigating the desensitization properties of the D3 receptor and trying to distinguish the individual role of calcium channels and GIRK channels in modulating secretory activity.

\section{REFERENCES}

Accili D, Fishburn CS, Drago J, Steiner H, Lachowicz JE, Park BH, Gauda EB, Lee EJ, Cool MH, Sibley DR, Gerfen CR, Westphal H, Fuchs S (1996) A targeted mutation of the D3 dopamine receptor gene is associated with hyperactivity in mice. Proc Natl Acad Sci USA 93:1945-1949.

Angelson JK, Betz WJ (1997) Monitoring secretion in real time: capacitance, amperometry, and fluorescence compared. Trends Neurosci 20:281-287

Betz WJ, Mao F, Smith CB (1996) Imaging exocytosis and endocytosis. Curr Opin Neurobiol 6:365-371.

Bonci A, Grillner P, Mercuri NB, Bernardi G (1998) L-type calcium channels mediate a slow excitatory synaptic transmission in rat midbrain dopaminergic neurons. J Neurosci 18:6693-6703.

Bouthenet ML, Souil E, Martres MP, Sokoloff P, Giros B, Schwartz JC (1991) Localization of dopamine D3 receptor mRNA in the rat brain using in situ hybridization histochemistry: comparison with dopamine D2 receptor mRNA. Brain Res 564:203-219.

Bowery B, Rothwell LA, Seabrook GR (1994) Comparison between the pharmacology of dopamine receptors mediating the inhibition of cell firing in rat brain slices through the substantia nigra pars compacta and ventral tegmental area. Br J Pharmacol 112:873-880.

Burris KD, Pacheco MA, Filtz TM, Kung M-P, Kung HF, Molinoff PB (1995) Lack of discrimination of agonist for D2 and D3 dopamine receptors. Neuropsychopharmacology 12:335-345.

Carmeliet P, Denef C (1989) Synthesis and release of acetylcholine by normal and tumoral pituitary corticotrophs. Endocrinology 124: $2218-2227$.

Dunlap K, Luebke JI, Turner TJ (1995) Exocytotic calcium channels in mammalian central neurons. Trends Neurosci 18:89-98.

Freedman SB, Patel S, Marwood R, Emms F, Seabrook GR, Knowles MR, McAllister G (1994) Expression and pharmacological characterization of the human D3 receptor. J Pharmacol Exp Ther 268:417-426.

Garcia DE, Brown S, Hille B, Mackie K (1998) Protein kinase C disrupts cannabinoid actions by phosphorylation of the CB1 cannabinoid receptor. J Neurosci 18:2834-2841.

Gobert A, Lejeune F, Rivet JM, Cistarelli L, Millan MJ (1996) Dopamine D3 (auto) receptors inhibit dopamine release in the frontal cortex of freely moving rats in vivo. J Neurochem 66:2209-2212.

Jones SVP (1992) m4 muscarinic receptor subtype activates an inwardly rectifying potassium conductance in AtT-20 cells. Neurosci Lett 147:125-130.

Koeltzow TE, Xu M, Cooper DC, Hu X-T, Tonegawa S, Wolf ME, White FJ (1998) Alterations in dopamine release, but not dopamine autoreceptor function, in dopamine D3 receptor mutant mice. J Neurosci 18:2231-2238.

Koh D-S, Hille B (1997) Modulation by neurotransmitters of catecholamine secretion from sympathetic ganglion neurons detected by amperometry. Proc Natl Acad Sci USA 94:1506-1511.

Kozasa T, Kaziro Y, Ohtsuka T, Grigg JJ, Nakajima S, Nakajima Y (1996) G-protein specificity of the muscarine-induced increase in an inward rectifier potassium current in AtT-20 cells. Neurosci Res 26:289-297.

Kuzhikandathil EV, Oxford GS (1997) Functional effect of dopamine receptor coupling to $\mathrm{G}$-protein-activated inward rectifier potassium channels in mammalian cells. Soc Neurosci Abstr 23:2281.

Loechner KJ, Kream RM, Dunlap K (1996) Calcium currents in a pituitary cell line (AtT-20): differential roles in stimulus-secretion coupling. Endocrinology 137:1429-1437.

Luebke JI, Dunlap K, Turner TJ (1993) Multiple calcium channel types control glutamatergic synaptic transmission in the hippocampus. Neuron 11:895-902.

Mackie K, Lai Y, Westenbroek R, Mitchell R (1995) Cannabinoids activate an inwardly rectifying potassium conductance and inhibit Q-type calcium currents in AtT-20 cells transfected with rat brain cannabinoid receptor. J Neurosci 15:6552-6561. 
Missale C, Nash SR, Robinson SW, Jaber M, Caron MG (1998) Dopamine receptors: from structure to function. Physiol Rev 78:189-225.

Momiyama T, Amano T, Todo N, Sasa M (1996) Inhibition by a putative antipsychotic quinolinone derivative (OPC-14597) of dopaminergic neurons in the ventral tegmental area. Eur J Pharmacol 310:1-8.

Nicola SM, Malenka RC (1997) Dopamine depresses excitatory and inhibitory synaptic transmission by distinct mechanisms in the nucleus accumbens. J Neurosci 17:5697-5710.

Overton PG, Clark D (1997) Burst firing in midbrain dopaminergic neurons. Brain Res Brain Res Rev 25:312-334.

Patel YC, Panetta R, Escher E, Greenwood M, Srikant CB (1994) Expression of multiple somatostatin receptor genes in AtT-20 cells. J Biol Chem 269:1506-1509.

Reisine T, Wang HL, Guild S (1988) Somatostatin inhibits cAMPdependent and cAMP-independent calcium influx in the clonal pituitary cell line AtT-20 through the same receptor population. J Pharmacol Exp Ther 245:225-231.

Richardson UI, Schonbrunn A (1981) Inhibition of adrenocorticotropin secretion by somatostatin in pituitary cells in culture. Endocrinology 108:281-290.

Rivet J-M, Audinot V, Gobert A, Peglion J-L, Millan MJ (1994) Modulation of mesolimbic dopamine release by the selective dopamine D3 receptor antagonist, (+)-S-14297. Eur J Pharmacol 265:175-177.

Robinson SW, Caron MG (1997) Selective inhibition of adenylyl cyclase type V by the dopamine D3 receptor. Mol Pharmacol 52:508-514.

Schwartz JC, Levesque D, Martres MP, Sokoloff P (1993) Dopamine D3 receptor: basic and clinical aspects. Clin Neuropharmacol 16:295-314.

Seabrook GR, Kemp JA, Freedman SB, Patel S, Sinclair HA, McAllister G (1994) Functional expression of human D3 dopamine receptors in differentiated neuroblastoma X glioma NG108-15 cells. Br J Pharmacol 111:391-393.
Suaud-Chagny MF, Chergui K, Chouvet G, Gonon F (1992) Relationship between dopamine release in the rat nucleus accumbens and the discharge activity of dopaminergic neurons during local in vivo application of amino acids in the ventral tegmental area. Neuroscience 49:63-72.

Takano K, Takano JY, Kozasa T, Nakajima S, Nakajima Y (1997) Different G-proteins mediate somatostatin-induced inward rectifier $\mathrm{K}^{+}$ currents in murine brain and endocrine cells. J Physiol (Lond) 502:559-567.

Tepper JM, Sun B-C, Martin LP, Creese I (1997) Functional roles of dopamine D2 and D3 autoreceptors on nigrostriatal neurons analyzed by antisense knock-down in vivo. J Neurosci 17:2519-2530.

Turner TJ, Adams ME, Dunlap K (1993) Multiple calcium channel types coexist to regulate synaptosomal neurotransmitter release. Proc Natl Acad Sci USA 90:9512-9518.

Umemiya M, Raymond L (1997) Dopaminergic modulation of excitatory postsynaptic currents in rat neostriatal neurons. J Neurophysiol 78:1248-1255.

Viana F, Hille B (1996) Modulation of high voltage-activated calcium channels by somatostatin in acutely isolated rat amygdaloid neurons. J Neurosci 16:6000-6011.

Winkler A, Papsdorf G, Odarjuk J, Siems WE, Fickel J, Melzig MF (1995) Expression and characterization of the substance P (NK1) receptor in the rat pituitary and AtT-20 mouse pituitary tumor cells. Eur J Pharmacol 291:51-55.

Wu LG, Saggau P (1994) Pharmacological identification of two types of presynaptic voltage-dependent calcium channels at the CA3-CA1 synapses of the hippocampus. J Neurosci 14:5613-5622.

Zeilhofer HU, Muller TH, Swandulla D (1996) Calcium channel types contributing to excitatory and inhibitory synaptic transmission between individual hypothalamic neurons. Pflügers Arch 432:248-257. 